\title{
DETERMINATION OF INDIVIDUAL GLUCOSE THRESHOLD USING PHARMACY PORTABLE BLOOD GLUCOSE METER
}

\author{
DETERMINAÇÃO DO LIMIAR GLICÊMICO INDIVIDUAL COM O USO DE GLICOSÍMETRO PORTÁTIL DE FARMÁCIA
}

DETERMINACIÓN DEL UMBRAL GLUCÉMICO INDIVIDUAL CON EL USO DE GLUCÓMETRO PORTÁTIL DE FARMACIA

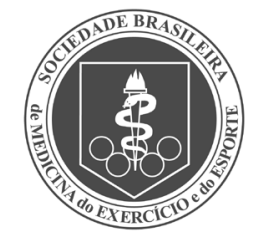

Original Article ARTIGO ORIGINAL Artículo Original
Nuno Manuel Frade de Sousa (Physical Education Professional) Aloísio Barbosa da Silva Júnior' (Physical Education Professional) Raquel de Souza Mairink' (Physical Education Professional) Danilo Rodrigues Bertucci (Physical Education Professional) Markus Vinícius Campos Souza ${ }^{3}$ (Physical Education Professional) Raul Agostinho Simões Martins ${ }^{4}$ (Physical Education Professional)

1. Faculdade Estácio de Sá, Exercise Physiology and Measurements and Assessment Laboratory, Department of Physical Education, Vitória, ES, Brazil.

2. Universidade Estadual Paulista (UNESP), Department of Physical Education, Rio Claro, SP, Brazil. 3. Universidade Federal do Triângulo Mineiro (UFTM) Department of Sports Sciences, Uberaba, MG, Brazil. 4. Universidade de Coimbra, Faculdade de Ciências do Desporto e Educação Física, Coimbra, Portugal.

\section{Correspondence:}

Nuno Manuel Frade de Sousa. Faculdade Estácio de Sá de Vitória. Av. Dr. Herwan Modenese Wanderley, 1001, Jardim Camburi, Vitória, ES, Brasil. 2990640. nunosfrade@gmail.com

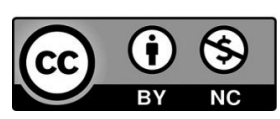

\begin{abstract}
Introduction: The individual glucose threshold (IGT) has been used to estimate the anaerobic threshold with low-cost analyses and shorter times. However, the reliability of the glycemic analysis using a portable pharmacy glucose meter has received little attention. Objective: To identify the IGT using a portable glucose meter and to compare it with the ventilatory threshold (VT). Methods: Fourteen active, healthy men $(25.9 \pm 3.2$ years; \% $\mathrm{BF}=17.9$ $\pm 3.7 \%$ ) performed an incremental treadmill test. The anaerobic threshold was identified by two different methods: (1) IGT, corresponding to the intensity of the lowest glucose value during the test; and (2) VT, corresponding to the break in linearity of the ventilation curve and an increase in the respiratory oxygen equivalent, without an equivalent increase in carbon dioxide. Results: There were significant differences between VT $(9.9 \pm 1.2 \mathrm{~km} / \mathrm{h})$ and IGT $(9.5 \pm$ $1 / 1 \mathrm{~km} / \mathrm{h}$ ), corresponding to $75.4 \pm 9.2$ and $72.5 \pm 10.4 \% \mathrm{VO}_{2 \text { max }}$ respectively. The methods presented high correlation $(r=0.82, p=0.002)$ and the Bland-Altman technique showed agreement between IGT and VT, with a mean difference of $0.5 \mathrm{~km} / \mathrm{h}$. Conclusion: It was possible to determine the intensity of IGT by the glycemic response in the incremental test using a portable glucose meter. The IGT underestimated the intensity of VT by approximately $0.5 \mathrm{~km} / \mathrm{h}$, but with a high correlation and agreement between them. Level of evidence III, Case-Controle Study.
\end{abstract}

Keywords: Anaerobic threshold; Ventilatory anaerobic threshold; Blood glucose.

\section{RESUMO}

Introdução: O limiar glicêmico individual (LGI) tem sido utilizado para estimar o limiar anaeróbico com baixo custo das análises e também em menor tempo. Entretanto, dá-se pouca atenção para a confiabilidade das análises glicêmicas por meio do glicosímetro portátil de farmácia. Objetivo: Determinar o LGI por meio de glicosímetro portátil e comparar com o limiarventilatório (LV). Métodos: Catorze homens saudáveis e ativos (25,9 $\pm 3,2$ anos; \%G $=17,9 \pm 3,7 \%)$ realizaram teste incrementalem esteira. Determinou-se o limiar anaeróbico por duas metodologias: (1) LGI, correspondendo à intensidade do menor valor glicêmico durante o teste; (2) LV, correspondendo à quebra da linearidade da curva da ventilação e aumento do equivalente respiratório de oxigênio sem aumento do equivalente de dióxido de carbono. Resultados: Foram observadas diferenças significativas entre $L V(9,9 \pm 1,2 \mathrm{~km} / \mathrm{h})$ e $L \mathrm{Gl}(9,5 \pm 1,1 \mathrm{~km} / \mathrm{h})$, correspondendo a 75,4 $\pm 9,2 \mathrm{e}$ $72,5 \pm 10,4 \%$ VO2máx, respectivamente. As duas metodologias apresentaram correlação alta $(r=0,82 ; p=0,002)$ entre si. A técnica de Bland-Altman evidenciou concordância entre os métodos $L G l$ e LV, com uma diferença média de $0,5 \mathrm{~km} / \mathrm{h}$. Conclusão: Foi possivivel determinar a intensidade do LGl por meio da resposta glicêmica em teste incremental com o uso de glicosímetro portátil de farmácia. O LG subestimou em aproximadamente $0,5 \mathrm{~km} / \mathrm{h}$ a intensidade do LV, no entanto, com alta correlação e concordância entre eles. Nível de evidência III, Estudo de Caso-controle.

Descritores: Limiar anaeróbio; Limiar anaeróbico ventilatório; Glicemia.

\section{RESUMEN}

Introducción: El umbral glucémico individual (UGI) ha sido utilizado para estimar el umbral anaeróbico con bajo costo de los análisis y también en menor tiempo. Sin embargo, se presta poca atención a la confiabilidad de los análisis glucémicos a través del glucómetro portátil de farmacia. Objetivo: Determinar el U Gl a través de glucómetro portátil y comparar con el umbral de ventilación (UV). Métodos: Catorce hombres sanos y activos (25,9 $\pm 3,2$ años; $\% G=17,9 \pm 3,7 \%)$ realizarán una prueba incremental en cinta. El umbral anaeróbico se determinó mediante dos metodologías: (1) UGI correspondiente a la intensidad del valor glucémico más bajo durante la prueba; (2) UV, correspondiente a la quiebra de la linealidad de la curva de la ventilación y aumento del equivalente respiratorio de oxígeno sin aumento del equivalente de dióxido de carbono. Resultados: Se observaron diferencias significativas entre UV $(9,9 \pm 1,2 \mathrm{~km} / \mathrm{h})$ y UGI $(9,5 \pm 1,1 \mathrm{~km} / \mathrm{h})$, correspondiendo a 75,4 $\pm 9,2$ y $72,5 \pm 10,4, \% \mathrm{VO}_{2}$ max, respectivamente. Las dos metodologías presentaron una correlación alta $(r=0,82, p=0,002)$ entre sí. La técnica de Bland-Altman evidenció concordancia entre los métodos UGI y UV, con una diferencia media de 0,5 km/h. Conclusión: Fue posible determinar la intensidad del UGI por medio de la respuesta glucémica en prueba incremental con el uso de glucómetro portátil de farmacia. El UGI subestimó en aproximadamente 0,5 km/h la intensidad del UV, sin embargo, con alta correlación y concordancia entre ellos. Nivel de evidencia III, Estudio de caso-control.

Descriptores: Umbral anaerobio; Umbral anaeróbico ventilatorio; Glucemia. 


\section{INTRODUCTION}

During incremental tests, glucose concentration decreases to the lactate threshold (LT) and then begins to increase ${ }^{1}$. This glycaemic increase after reaching LT is due to higher sympathetic activity that induces a higher rate of glycogenolysis in the liver ${ }^{2}$. Thus, the intensity of the exercise at which the glucose concentration begins to rise during the incremental test is called the Individual Glycaemic Threshold (IGT) and has been observed during incremental tests ${ }^{3}$. The IGT is a methodology used to understand the glycaemic responses in order to determine the anaerobic threshold ${ }^{4}$. In addition, it seems to demarcate an exercise intensity above which glucose production exceeds its uptake, and which does not differ from the ventilatory threshold (VT) and LT identified in healthy young individuals. 5,6

The method considered gold standard for the evaluation of the anaerobic threshold and aerobic fitness is the analysis of the responses of lactate blood concentrations ${ }^{4,6}$. Also, it can be determined by ventilatory responses, which has the advantage of not being invasive and widespread used in the prescription of exercise for special groups, however, these evaluations require high-cost devices and it is necessary that exercise physiology experts identify the intensity where the anaerobic threshold occurs $^{7}$. Therefore, in order to find easy to apply and reliable physiological parameters, research has been conducted to study blood glycaemia, aiming at the determination of the anaerobic threshold.

Alternatively, the IGT has been used to estimate the anaerobic threshold with low cost of analysis and also in shorter duration ${ }^{3}$. Previous studies have shown high correlation between IGT and anaerobic threshold', minimum lactate speed ${ }^{5}, \mathrm{VT}^{5}$ onset of blood lactate accumulation ${ }^{3}$. Studies have also shown the importance of this methodology to evaluate and prescribe running training $s^{5}$, swimming ${ }^{8}$, cycle ergometers ${ }^{9}$ and contact sports such as Greco-Roman wrestling ${ }^{10}$.

Rocha et al ${ }^{11}$, evaluated the IGT in soldiers using the portable blood glucometer and observed that this device is sensitive enough to evaluate the blood glucose changes of soldiers submitted to the training, thus, these results open new perspectives for the control of exercise prescription in an accessible and low cost. In view of this, as there is little attention to the reliability of the blood glucose monitoring device by means of the pharmacy glucometer, the objective of the study was to determine the IGT by means of a portable glucometer and to compare it with the VT. The hypothesis was that the portable glucometer can be used to determine the anaerobic threshold with good reliability.

\section{MATERIALS AND METHODS \\ Participants}

The study included 14 physically active men aged $25.9 \pm 3.2$ years, body mass of $78.4 \pm 11.0 \mathrm{~kg}$ and fat percentage of $17.9 \pm 3.7 \%$. Smokers, anabolic steroid users, known history of cardiovascular disease, respiratory disease, diabetes, hypertension, hormone disorder, muscle damage in the last 12 months, nutritional supplementation in the last six months, and negative response to PAR-Q were excluded from the study. All participants were informed in detail about the procedures used and agreed to voluntarily participate in the study, signing a free and informed consent form, in accordance with the ethical principles of research involving humans established in the Helsinki declaration and previously approved by the local ethics committee (CAEE: 494.2009).

\section{Incremental Test Protocol}

The test was elaborated according to Bentley et al, which presents norms for the accomplishment of maximum tests ${ }^{12}$. The test started at a speed of $5 \mathrm{~km} / \mathrm{h}$ and every 2 minutes the speed was increased by 1 $\mathrm{km} / \mathrm{h}$ until exhaustion. The following criteria for interrupting the test were adopted: (i) voluntary fatigue of the participant; (ii) the achievement of plateau in the consumption of oxygen; (iii) achieve maximum heart rate, calculated by the formula 220 - age; (iv) reach a value greater than 1.1 of the respiratory quotient ${ }^{13}$. The test was considered valid when two of the five interruption criteria described above were achieved. The determination of the anaerobic threshold was performed by means of plasma glucose concentrations and ventilatory parameters.

\section{Glycaemic threshold}

The collection of a blood sample of approximately 0.7 to $3.0 \mu \mathrm{l}$ was performed on the index finger in the last 10 seconds of each stage, from $6 \mathrm{~km} / \mathrm{h}$. Glucose concentration was determined with the use of a portable glucometer acquired in pharmacy (Breeze ${ }^{\circledR} 2$, Bayer). The IGT was determined by means of the glucose concentration kinetics during incremental test, being defined as the exercise intensity and oxygen consumption (VO2) in which the glucose concentration reached the lowest value immediately before starting to increase.

\section{Ventilatory threshold}

The expired gases were measured continuously using the gas analyser (Metalyser II, Cortex) throughout the test. The calibration of the gas analysis equipment was performed before each test according to the manufacturer's manual. The results obtained in the last 60 seconds of each stage were considered for the identification of ventilatory parameters. The highest $\mathrm{VO}_{2}$ obtained in voluntary exhaustion was considered $\mathrm{VO}_{2}$ max.

$\mathrm{VT}$ was identified by the breakdown of linearity of ventilation (VE) and carbon dioxide production $\left(\mathrm{VCO}_{2}\right)$ and increase in the respiratory equivalent of oxygen $\left(\mathrm{VE} / \mathrm{VO}_{2}\right)$ without the concomitant increase in the respiratory equivalent of carbon dioxide $\left(\mathrm{VE} / \mathrm{VCO}_{2}\right)$. The method of determination was performed by visual inspection with the determination of two experienced evaluators. The results were compared between the evaluators and, when discrepancies greater than $5 \%$ occurred, the graphs were re-evaluated. The mean value presented by the two evaluators was assumed as the VT, represented by physical effort intensity $\left(\mathrm{km} \cdot \mathrm{h}^{-1}\right)$ and $\mathrm{VO}_{2}$.

\section{Statistical analysis}

Results are expressed as mean \pm standard deviation (SD). All analysed variables presented normal distribution (Shapiro-Wilk). Student's t-test for dependent samples was used to compare velocity and $\mathrm{VO}_{2}$ between IGT and VT. Correlation and agreement between IGT and VT was performed using the Pearson correlation coefficient and Bland-Altman analysis ${ }^{14}$, respectively. The software used was SPSS version 17.0 (Somers, NY, USA) with significance level of $p \leq 0.05$.

\section{RESULTS}

The $\mathrm{VO}_{2}$ máx of volunteers was 49,1 $\pm 5,3 \mathrm{ml}$.(kg.min) ${ }^{-1}$ and the maximum speed reached during the incremental test was $13.7 \pm 1.1 \mathrm{~km} \cdot \mathrm{h}^{-1}$. From the 14 participants in the study, it was possible to observe the IGT in 12 individuals and the VT in 13 subjects. Thus, the comparisons between IGT and VT were performed only with 11 volunteers, those who were allowed to simultaneously identify the anaerobic threshold by the two methodologies.

Figure 1 shows the determination of the VT and IGT for an assessed person. As can be seen, the glucose curve is " $U$ " shaped and the speed corresponding to the lowest glucose concentration was considered the IGT $\left(9 \mathrm{~km} \cdot \mathrm{h}^{-1}\right)$. The ventilatory threshold was determined by the linearity of the LV curve $\left(9 \mathrm{~km} \cdot \mathrm{h}^{-1}\right)$.

Table 1 shows the velocity and $\mathrm{VO}_{2}$ corresponding to IGT and VT. As can be observed, the velocity and $\mathrm{VO}_{2}$ corresponding to the IGT were significantly lower ( $p=0.025$ and $p=0.041$, respectively) in relation to the 
VT. When the comparison was performed in relation to $\% \mathrm{VO}_{2} \mathrm{max}$, the IGT also presented significantly lower values $(p=0.040)$ in relation to the VT.

The two methodologies for determining the anaerobic threshold presented a high correlation ( $r=0.82, p=0.002$ ) with each other. The Bland-Altman technique showed a concordance between the IGT and VT methods, both in exercise intensity and in VO2 reached at the anaerobic threshold (Figure 2 ).

The bias $\pm 95 \%$ of the concordance limits for the comparisons between the IGT and VT velocities was $0.5 \pm 1.3 \mathrm{~km} . \mathrm{h}^{-1}$ between the $\mathrm{VO}_{2}$ corresponding to IGT and VT was $1.5 \pm 5.0 \mathrm{ml}$ (kg.min) - 1 , with only one individual outside the limits of agreement for the two analyses.
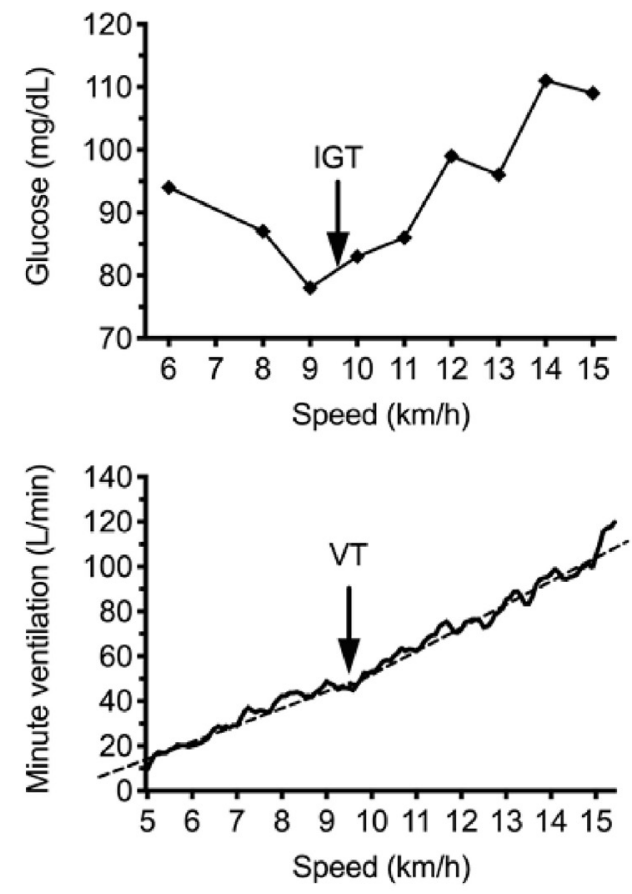

Figure 1. Anaerobic threshold determiation by ventilatory parameters (VT) and blood glucose concentration (IGT) for volunteer number 7 .

Table 1. Mean \pm SD of speed and oxygen consumption at individual glycemic threshold and ventilatory threshold.

\begin{tabular}{c|c|c}
\hline & VT & IGT \\
\hline Speed $(\mathrm{km} / \mathrm{h})$ & $9,9 \pm 1.2$ & $9.5 \pm 1.1^{*}$ \\
\hline $\mathrm{VO}_{2}, \mathrm{ml} .(\mathrm{kg} . \mathrm{min})^{-1}$ & $36.6 \pm 4.4$ & $35.1 \pm 3.6^{*}$ \\
\hline $\mathrm{VO}_{2}$ máx, \% & $75.4 \pm 9.2$ & $72.5 \pm 10.4^{*}$ \\
\hline
\end{tabular}

$\mathrm{VO}_{2}$ máx, maximal oxygen consumption; $\mathrm{VT}$, ventilatory threshold; IGT, individual glycemic threshold; ${ }^{*} \mathrm{p}<0.05$ for $\mathrm{VT}$.

\section{DISCUSSION}

The present study compared the use of glycaemia determined in a portable glucometer to identify the maximum incremental anaerobic threshold in young, healthy and physically active individuals with ventilatory parameters, which are already widely reported in the literature. It was possible to determine the IGT for approximately $85 \%$ of the studied sample, however, the intensity and oxygen consumption in IGT was lower than the values determined by the VT technique. Despite this difference, the intensity differed by only $0.5 \mathrm{~km} \cdot \mathrm{h}^{-1}$ and a high correlation and agreement between the methods used.

During the incremental test used in our methodology, the glycaemia progressively decreased to an intensity that, when reached, occurred an increase. The glycaemic response was similar to that described by other authors during incremental aerobic exercise in running ${ }^{5,15}$ and cycle
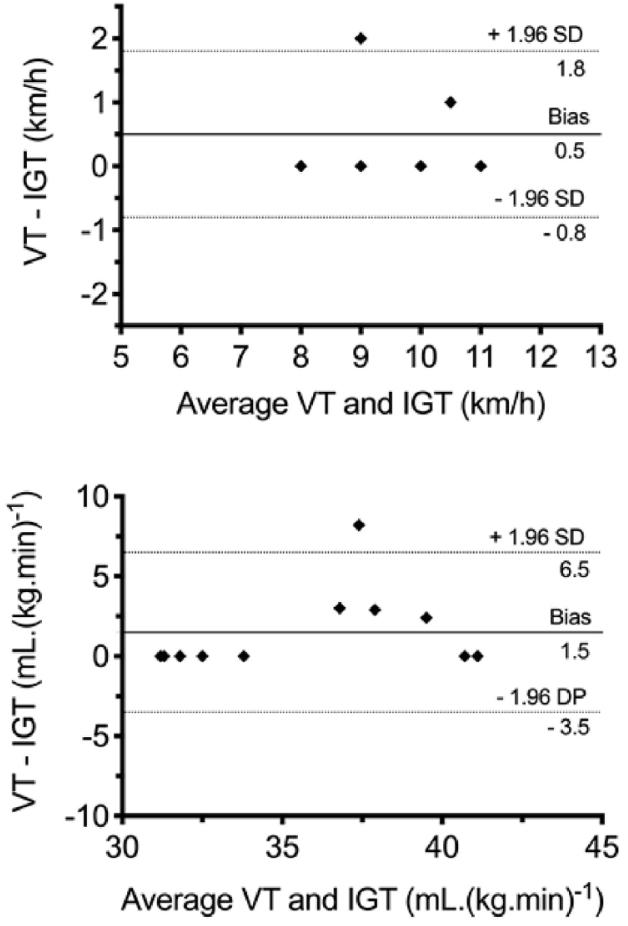

Figure 2. Bland-Altman analysis showing the bias and limits of concordance (1.96 SD) between speed and oxygen consumption at individual anaerobic threshold (IGT) and ventilatory threshold (VT).

ergometer $^{16}$, intensity that corresponded to the anaerobic threshold. In addition, it has been shown that the glycaemic response can identify the anaerobic threshold when incremental tests are performed after induction of lactic acidosis in running ${ }^{1,17}$, cycle ergometer ${ }^{16}$ e swimming ${ }^{8}$, both in individuals with athletes in non-athletes. In the present study, although the glycaemic response was similar to other authors, the IGT intensity did not coincide with the intensity of the VT, presenting an anaerobic threshold response determined by ventilatory parameters. However, the difference between the techniques was very small, which in practice may not represent a relevant difference for training prescription in individuals aiming to improve aerobic performance for health purposes. It is necessary to emphasize that the glucometer used in this research was a portable glucometer and widely available in the pharmaceutical market, with readings with greater error margins than scientific glucometers, such as those used in previous research 5,15,16.

Thus, the difference in the intensity of the anaerobic threshold between the techniques used can be justified due to the greater margin of error of the glucose values determined by the portable glucometer. The margin of error can also explain the fact that in $14 \%$ of the sample it was not possible to determine IGT. Although it presents a greater margin of error than portable, Rocha et al ${ }^{11}$ demonstrated that this type of device was sensitive enough to identify the changes caused by training in the glycaemic response, since IGT showed a shift to the right after a period of 30 and 60 days of military training. Dellavati et al., when using a portable blood glucose meter, concluded in their study that there is agreement between the methods of determining the anaerobic threshold also in patients with type 2 diabetes. Simões et al ${ }^{6}$ also demonstrated that, in addition to the similarity between the intensity of the VT and IGT, there is a high correlation and agreement between VT and IGT in diabetics and non-diabetics. The high correlation and agreement was also observed in the present study, with an equal correlation $(r=0.82)$ to the study of Simões et $\mathrm{al}^{6}$ and only one individual outside the limits of agreement, 
with a bias of $0.5 \mathrm{~km} . \mathrm{h}^{-1}$, which can be considered an irrelevant difference for the practical application. The difference of $0.5 \mathrm{~km} \cdot \mathrm{h}^{-1}$, according to the Bland-Altman plot, is a consistent error, that is, the measurement error of the portable glucometer seems to be constant, which allows to identify changes in glycaemic response to training, as stated by Rocha et al ${ }^{11}$. Sotero et $\mathrm{al}^{3}$ analysed whether the running speed corresponding to the IGT identified by the minimum glucose protocol could predict the maximum stable phase of lactate. They concluded that the velocity corresponding to the minimum glucose can predict the maximum lactate steady state.

In an attempt to justify IGT, several studies confirm that the anaerobic threshold is identified at an exercise intensity above which metabolic acidosis and elevated blood glucose concentration occur ${ }^{1,5,6}$. Considering that the anaerobic threshold represents the point of supplementation of the energy supply by the anaerobic system, the IGT determines the intensity of the exercise in which the elevation of blood glucose concentration occurs, which can be justified by the predominance transition of metabolic pathways. Simões et $\mathrm{al}^{5}$ and Rose and Richter $^{18}$ reported that the initial downward response of the glycaemic curve is due to increased phosphorylation of proteins related to glucose uptake by skeletal muscle, resulting in a greater amount of type 4 glucose transporters (GLUT4) to the cell membrane. From intensities corresponding to approximately the anaerobic threshold, the increase of glycaemia is due to a greater adrenergic activity, inducing hepatic glycogenolysis as well as greater gluconeogenic activity mediated by glucagon. These mechanisms of glycaemic control are exacerbated at high intensities, mainly from the anaerobic threshold, and may explain the glycaemic response at increasing intensities ${ }^{18}$. In addition, Rose and Richter ${ }^{18}$ reported that during intense exercise inhibition of the enzyme hexokinase occurs, limiting the influx and phosphorylation of glucose in muscle cytoplasm. Lastly, Sahlin ${ }^{19}$ also demonstrated that glycogen phosphatase and phosphofructokinase enzymes control the degradation of glycogen and glucose. During exercise above the anaerobic threshold, the intramuscular pH falls, which inhibits the action of these enzymes and also leads to a decrease in glucose uptake. Thus, the IGT demarcates a transition from the predominance of glucose uptake to the production of glucose stimulated by catecholamines and glucagon during high intensity exercises.

Considering the results obtained, the use of portable pharmacy glucometer to measure the anaerobic threshold through the glycaemic response can be considered a fast methodology, low cost, easy to acquire equipment and applicable to daily training, helping both practitioners of physical activity and coaches to prescribe proper aerobic training. However, the lack of comparison of the IGT with the gold standard for determining the anaerobic threshold that is through blood lactate dosages should be considered a limitation of the study, leading to more cautious conclusions regarding the generalization of the results. In addition, it will be important to apply this type of low-cost and easy-to-acquire methodology to different populations, especially people with diabetes, in whom glycaemic response to exercise is key to training prescription.

\section{CONCLUSIONS}

It was possible to determine the IGT intensity by means of the glycaemic response in an incremental test with the use of portable pharmacy glucometer. The IGT underestimated in approximately $0.5 \mathrm{~km}$ / $\mathrm{h}$ the intensity of the VT, however, with high correlation and agreement between them. These results open new perspectives for the control of training prescription in an accessible and inexpensive way.

All authors declare no potential conflict of interest related to this article

AUTHORS' CONTRIBUTIONS: Each author made significant individual contributions to this manuscript. NMFS (0000-0001-5854-616X)* and DRB (0000-0002-9833-2390)* were the main contributors to the writing of the manuscript. AJ, RASM (0000-0003-1194-4560)* and NS took part in the data collection. NS and MVCS (0000-0002-8088-2423)* evaluated the data from the statistical analysis. NS, AJ and RM performed the bibliographic research. MS and RM performed the revision of the manuscript and contributed to the intellectual concept of the study. ${ }^{*} \mathrm{ORCID}$ (Open Researcher and Contributor ID).

\section{REFERENCES}

1. Simoes HG, Grubert Campbell CS, Kokubun E, Denadai BS, Baldissera V. Blood glucose responses in humans mirror lactate responses for individual anaerobic threshold and for lactate minimum in track tests. Eur J Appl Physiol Occup Physiol. 1999;80(1):34-40.

2. Simoes HG, Hiyane WC, Benford RE, Madrid B, Prada FA, Moreira SR, et al. Lactate threshold prediction by blood glucose and rating of perceived exertion in people with type 2 diabetes. Percept Mot Skills. 2010;111(2):365-78.

3. Sotero RC, Pardono E, Landwehr R, Campbell CS, Simoes HG. Blood glucose minimum predicts maximal lactate steady state on running. Int J Sports Med. 2009;30(9):643-6.

4. Jacobs I. Blood lactate. Implications for training and sports performance. Sports Med. 1986;3(1):10-25.

5. Simoes HG, Campbell CS, Kushnick MR, Nakamura A, Katsanos CS, Baldissera V, et al. Blood glucose threshold and the metabolic responses to incremental exercise tests with and without prior lactic acidosis induction. Eur J Appl Physiol. 2003;89(6):603-11.

6. Simoes HG, Moreira SR, Moffatt RJ, Campbell CS. [Methods to identify the anaerobic threshold for type-2 diabetic and non-diabetic subjects]. Arq Bras Cardiol. 2010;94(1):71-8

7. Gitt AK, Wasserman K, Kilkowski C, Kleemann T, Kilkowski A, Bangert M, et al. Exercise anaerobic threshold and ventilatory efficiency identify heart failure patients for high risk of early death. Circulation. 2002;106(24):3079-84.

8. Ribeiro L, Balikian P, Malachias P, Baldissera V. Stage length, spline function and lactate minimum swimming speed. J Sports Med Phys Fitness. 2003;43(3):312-8.

9. Junior PB, Neiva CM, Denadai BS. Effect of an acute beta-adrenergic blockade on the blood glucose response during lactate minimum test. J Sci Med Sport. 2001;4(3):257-65.
10. Karnincic H. Glucose dynamics can evaluate state of anaerobic fitness in wrestling?! Coll Antropol. 2013;37(Suppl 2):101-6.

11. Rocha C, Canellas A, Monteiro D, Antoniazzi M, Azevedo PH. Changes in individual glucose threshold during military training. Int J Sports Med. 2010;31(7):482-5.

12. Bentley DJ, Newell J, Bishop D. Incremental exercise test design and analysis: implications for performance diagnostics in endurance athletes. Sports Med. 2007;37(7):575-86.

13. Yazbek Junior P, Carvalho RT, Sabbag LM, Battistella LR. Ergoespirometria. Teste de esforço cardiopulmonar, metodologia e interpretação. Arq Bras Cardiol. 1998;71(5):719-24.

14. Bland JM, Altman DG. Statistical methods for assessing agreement between two methods of clinical measurement. Lancet. 1986;1(8476):307-10.

15. Simões HG, Campbell CSG, Kokubun E, Denadai BS, Baldissera V. Determination of maximal lactate steady state velocity: coincidence with lower blood glucose. Med Sci Sports Exerc. 1996;28:S68-77.

16. Campbell CSG, Simões HG, Denadai BS. Influence of glucose and caffeine administration on identification of the lactate threshold. Med Sci Sports Exerc. 1998;30(5):S327.

17. Simões HG, Campbell CSG, Baldissera V, Denadai BS, Kokubum E. Determinação do limiar anaeróbio por meio de dosagens glicêmicas e lactacidêmicas em testes de pista para corredores. Rev Paul Educ Física. 1998;12(1):17-30.

18. Rose AJ, Richter EA. Skeletal muscle glucose uptake during exercise: how is it regulated? Physiology 2005;20:260-70

19. Sahlin K. Metabolic factors in fatigue. Sports Med. 1992;13(2):99-107. 